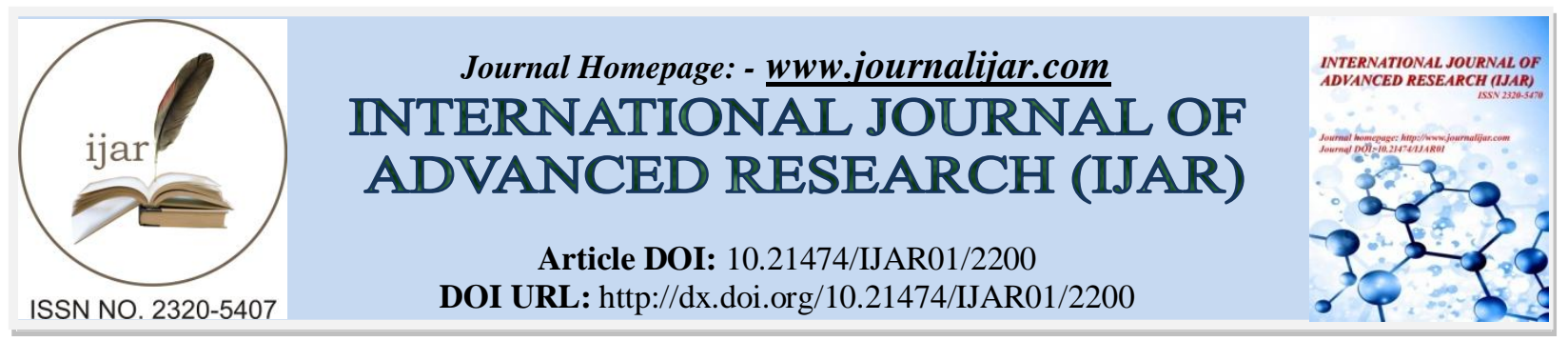

RESEARCH ARTICLE

\title{
CORRELATES BETWEEN TEACHER -STUDENT RELATIONSHIP SUPPORTIVENESS AND ADOLESCENTS' PSYCHOLOGICAL ADJUSTMENT.
}

Kariuki Scholastica Njeri.

Education Department, Affiliation: Daystar University, Nairobi.

\section{Manuscript Info}

Manuscript History

Received: 28 September 2016

Final Accepted: 30 October 2016

Published: November 2016

Key words:-

School supportiveness, teacher-student relationships, psychosocial adjustment, social helpfulness, pro-social behavior, risky behaviors.

\section{Abstract}

Children on average spend at least 15,000 hours in class rooms from age 4 or 5 until they leave high school (Meece \& Eccles, 2010). The institutions therefore are the critical contexts for nurturing desirable values, beliefs, principles and ideas. This is more so for Kenya in the view that behaviour problems among Kenyan secondary school students have been on the rise (Aloka, \& Bujuwoye, 2013). This study sought to establish the relationship between school supportiveness and adolescents' psychosocial development, with the intent to enhance adolescents' adjustment in school. The study employed a sample of 240 adolescents aged 13-18 and drawn from 4 Counties purposively selected from 47 Counties in Kenya. A final sample of 240 was obtained through multistage sampling strategy. The study was a descriptive correlational survey; it involved gathering data from adolescents using a questionnaire to assess the relationship between school supportiveness and adolescents' psychosocial adjustment. Findings showed that students-teachers relationship supportiveness was positively significantly correlated with adolescents' Psychosocial adjustment at $r 165^{*}, \mathrm{n} 222, \mathrm{p}=.014<.05$, prosocial behaviours at r. $170^{*}, \mathrm{n}=222, \mathrm{p} .011<.05$, social helpfulness at r. $149^{*}, \mathrm{n}=219, \mathrm{p}$ $.028<.05$, and resilience to risky behaviours at r.204**, $\mathrm{n}=218, \mathrm{p}$ $.003<.05$. It was concluded that teacher- student relationship supportiveness influences adolescents' social helpfulness, prosocial behaviours and resiliency to risky behaviours as well as overall psychosocial adjustment.

Copy Right, IJAR, 2016,. All rights reserved.

\section{Introduction:-}

It is generally assumed that schools nurture children's development. Children spend more time in school settings than any other (Meece \& Eccles, 2010). In schools, they are exposed to critical developmental experiences and becoming productive and independent members of the society (Morrison and Connor, 2002). School's climate and culture form significant affects of students' development (Hamre\& Pianta, 2007). The school experiences have been closely associated with students' adjustment outcome (Nye, Konstantopoulos, \& Hedge, 2004). The Kenya Ministry of Education listed goals of education include, promoting individual development and self-fulfillment, sound moral and religious values, responsibility and positive altitudes (MoE, 2010). Nevertheless, behaviour problems among Kenyan secondary school students continue to raise concerns to parents, teachers, principals and the Ministry of Education (Aloka, 2012). The students' antisocial behaviours have been on the increase (Aloka \& Bujuwoye, 
2013). The Daily Nation Friday (August 7, 2015) recorded a case whereby students who had closed school hired a Nairobi bound minibus to travel in and amidst loud music were smoking bhang. Torching of schools by students across the country was observed early in the year (Wanzara, July 20 2016). The antisocial behaviour status is noted amidst claims that Kenya's education system is experiencing challenges concerning teacher absenteeism, teacher competence, curriculum relevance and inadequate training resources (MoE, 2012). It could be that the educational inadequacies lead to insufficient training for positive psychosocial adjustment.

Mentorship and molding in the education sector has obvious gaps related to structure and quality of personnel (Policy Frame Work for Education, MoE 2012). In the circumstances, children face negative conditions in school and these can prevent positive learning (UNICEF, 2006). It could be that growing children are not being deliberately inculcated with desirable values, beliefs, principles and ideas at their formative age. From the foregoing, it is clear that behavior problems among Kenyan secondary school students have been on the rise in recent years. However, it is not clear whether Kenyan schools are supportiveness enough and if the schools roles mitigate psychosocial adjustment.

Kenya curriculum development institute (KCDI) efforts to enhance school supportiveness through life skills Education have been in place since January 2009 (Ministry of Public Health and Sanitation and Ministry of Education National School Health Strategy Implementation Plan 2010-2015). The aim was to mitigate risk behaviours and negative peer pressure. However, there is no documented evidence on the outcome. This study therefore sought to investigate how school supportiveness relates with adolescents' psychosocial adjustment, this paper is a findings report presentation on the relationship between teacher- student relationship supportiveness and adolescents' psychosocial adjustment.

\section{Theoretical Frame work:-}

This study was informed by reviews of Erikson (1968; 1985) psychosocial theory, Ecological theory by Bronfenbrenner (1979; 1995), models of psychosocial adjustment and Person Centered theory by Carl Rogers. The theories describe how child psychosocial development occurs in various contexts.

\section{Methods and Materials:-}

This research employed descriptive correlation survey design. Multi stage sampling designs was used in the study.

\section{Study population:-}

The research population comprised adolescents in secondary schools aged 13-18 years.

\section{Data Analysis:-}

The Statistical Package for the Social Sciences (SPSS) version 20, was used to analyse data, after the data was keyed in and the data sheet cleaned. The responses on school supportiveness and adolescents' psychosocial adjustment were valued and also computed into frequencies, percentages and mean scores. Mean scores cores were further converted into interval scores which allowed use of correlation statistics. Both Pearson and Spearman correlation coefficient were used to examine the relationship between school supportiveness and adolescents' psychosocial adjustment. The researcher tested statistical hypothesis in order to determine the relationship between school supportiveness and adolescents' psychosocial adjustment. One of the tested hypotheses was that 'School teacherstudent relationship supportiveness is not significantly related to adolescents' psychosocial adjustment'

\section{Results:-}

As shown in Table 1 the findings showed that $64 \%$ of the students felt that teachers loved, cared for them and were respectful. The mean score on the supportiveness was moderate support (3.570). In addition, 57\% confirmed that the teachers were always helpful whenever students were disturbed; the mean helpfulness (for helpfulness when disturbed) was moderate (3.5).

The students scored a mean of 2.923 (Low supportiveness) on the perception of teachers knowing them by name, $47 \%$ of the students disagreed that teachers knew them by name. A $35 \%$ of the students disagreed that lessons were a happy experience, the happiness in the classroom during lessons scored a mean of 3.117 (moderate supportive). 
Table 1:- Teacher -Pupil relationship supportiveness.

\begin{tabular}{|c|c|c|c|c|c|c|c|}
\hline $\begin{array}{l}\text { Students' Perceptions on their relationship with } \\
\text { Teachers. }\end{array}$ & $\mathrm{N}$ & $\begin{array}{c}\text { Mea } \\
\mathrm{n}\end{array}$ & $\begin{array}{l}\text { Strongly } \\
\text { Disagree }\end{array}$ & $\begin{array}{c}\text { Disagr } \\
\text { ee }\end{array}$ & $\begin{array}{l}\text { Not } \\
\text { Sure }\end{array}$ & $\begin{array}{c}\text { Agr } \\
\text { ee }\end{array}$ & $\begin{array}{c}\text { Strongly } \\
\text { Agree }\end{array}$ \\
\hline Trs. are Love, care and respectful & $\begin{array}{r}21 \\
9\end{array}$ & $\begin{array}{r}3.57 \\
08\end{array}$ & $0 \%$ & $18 \%$ & $18 \%$ & $53 \%$ & $11 \%$ \\
\hline Trs. Help when disturbed. & $\begin{array}{r}21 \\
9\end{array}$ & $\begin{array}{r}3.34 \\
70\end{array}$ & $4 \%$ & $24 \%$ & $15 \%$ & $47 \%$ & $10 \%$ \\
\hline Trs. are friendly and concerned. & $\begin{array}{r}22 \\
0\end{array}$ & $\begin{array}{r}3.43 \\
64\end{array}$ & $8 \%$ & $12 \%$ & $19 \%$ & $50 \%$ & $11 \%$ \\
\hline Trs. Know students by name. & $\begin{array}{r}22 \\
1\end{array}$ & $\begin{array}{r}2.92 \\
31\end{array}$ & $16 \%$ & $27 \%$ & $20 \%$ & $25 \%$ & $12 \%$ \\
\hline Lessons are a happy experience & $\begin{array}{r}22 \\
1\end{array}$ & $\begin{array}{r}3.11 \\
76\end{array}$ & $10 \%$ & $25 \%$ & $17 \%$ & $40 \%$ & $8 \%$ \\
\hline Trs. are always helpful & $\begin{array}{r}22 \\
0\end{array}$ & $\begin{array}{r}3.41 \\
82\end{array}$ & $14 \%$ & $11 \%$ & $11 \%$ & $45 \%$ & $19 \%$ \\
\hline
\end{tabular}

It was noted that $64 \%$ of the student agreed that teachers were always hopeful, the mean perception of general helpfulness was 3.418 (moderate supportiveness). It appears that students generally perceive to have above average care, love, respect and help from their teachers.

\section{Adolescents Psychosocial Adjustment:-}

The independent variable of the study was adolescents' psychosocial adjustment in Kenyan urban public schools. The aspects of adjustment that were measured included-emotionality, Industry, social helpfulness, self-worth and control, prosocial behaviours, resiliency to risky behaviours. The students were required to respond to a 5-point Likert scale items to describe the psychosocial behaviours. First, each of the students' behaviours findings are presented and then the correlation with school supportiveness are presented.

\section{Adolescents' Industry and Emotionality:-}

Adolescents industry, and emotionality were investigated using 6 items and 11 item respectively as shown in Table 2.

Table 2:- Adolescents' Industry, and Emotionality

\begin{tabular}{|c|c|c|c|c|c|c|c|c|c|c|}
\hline & & & & & \multicolumn{6}{|c|}{ Adolescents' Industry } \\
\hline & $\mathrm{N}$ & Missed & Mean & Std. Dev & $\begin{array}{l}\text { S/Dis } \\
\text { agree }\end{array}$ & Disagree & N/Sure & Agree & S/ Agree & $\begin{array}{l}\text { Tot } \\
\%\end{array}$ \\
\hline $\begin{array}{l}\text { I help with tasks at } \\
\text { home. }\end{array}$ & 220 & 2 & 4.52 & 0.878 & 3.6 & 0.9 & 1.4 & 28.2 & 65.9 & 100 \\
\hline $\begin{array}{l}\text { I feel motivated to } \\
\text { work for myself and } \\
\text { others. }\end{array}$ & 214 & 8 & 4.36 & 0.901 & 2.3 & 3.3 & 5.1 & 35 & 54.2 & 100 \\
\hline $\begin{array}{l}\text { I spend lots time not } \\
\text { knowing what to do. }\end{array}$ & 218 & 4 & 2.33 & 1.225 & 29.4 & 36.7 & 12.4 & 15.1 & 6.4 & 100 \\
\hline $\begin{array}{l}\text { I hang out in shopping } \\
\text { centres during } \\
\text { holidays. }\end{array}$ & 218 & 4 & 2.13 & 1.336 & 43.1 & 31.2 & 4.1 & 12.4 & 9.2 & 100 \\
\hline $\begin{array}{l}\text { I visit other people } \\
\text { during holidays. }\end{array}$ & 216 & 6 & 3.28 & 1.437 & 18.1 & 17.6 & 3.2 & 40.3 & 20.8 & 100 \\
\hline $\begin{array}{l}\text { I am hardworking at } \\
\text { school. }\end{array}$ & 218 & 5 & 4.1 & 0.908 & 1.4 & 5 & 13.3 & 43.1 & 37.2 & 100 \\
\hline & & & & & \multicolumn{6}{|c|}{ Adolescents' emotionality } \\
\hline I feel happy & 218 & 4 & 3.85 & 1.309 & 8.7 & 9.6 & 12.8 & 25.7 & 43.1 & 100 \\
\hline $\begin{array}{l}\text { I cry a lot when in } \\
\text { school }\end{array}$ & 210 & 12 & 1.86 & 1.258 & 56.7 & 23.3 & 4.3 & 8.6 & 7.1 & 100 \\
\hline $\begin{array}{l}\text { I feel like being alone } \\
\text { a lot. }\end{array}$ & 214 & 8 & 2.73 & 1.536 & 30.8 & 22 & 10.7 & 16.4 & 20.1 & 100 \\
\hline
\end{tabular}


Results showed that majority of the adolescents comprised $94.1 \%$ who help with home tasks while $5.9 \%$ disagreed that they help with home tasks. The mean perception for being helpful at home was 4.52 and a standard deviation of .0878. Most of the students comprising 89.2\% reported that they feel motivated to work for self; the motivation for work was rated at a mean of 4.36 and a standard deviation of .901 . It was noted that $80.3 \%$ consider themselves hardworking in school. The mean for hard work perception at school was 4.1 and standard deviation of 1.4 . However, $33.4 \%$ of the students spend a lot of time not knowing what to do and $21.6 \%$ reported that they hang out in the shopping centres during holidays a lot, $25.7 \%$ spent their time around shopping centres during holiday.

Another psychosocial adjustment variable that was examined was emotionality. The adolescents' emotionality was assessed using 3 items, the response rates ranged from $98.2-94.6 \%$. The findings show that majority comprising $68.8 \%$ feel happy when in school while $16 \%$ of them reported that they cry a lot and $47.2 \%$ spent time alone a lot while in school.

\section{Adolescents' Self Control and Worth:-}

An assessment of adolescents' psychosocial adjustment on self worth and control was done using 7 items as shown in Table 3.

Table 3:- Adolescents' Self control and Self Worth.

\begin{tabular}{|c|c|c|c|c|c|c|c|c|c|c|}
\hline & & & & & \multicolumn{5}{|c|}{$\%$ responses } & \multirow[b]{2}{*}{$\begin{array}{l}\text { Tot } \\
\%\end{array}$} \\
\hline & $\mathrm{N}$ & Missed & $\begin{array}{c}\text { Mea } \\
n\end{array}$ & $\begin{array}{l}\text { Std. } \\
\text { Dev }\end{array}$ & $\begin{array}{c}\text { Strongly } \\
\text { Disagre } \\
\mathrm{e}\end{array}$ & Disagree & $\begin{array}{l}\text { Not } \\
\text { Sure }\end{array}$ & Agree & $\begin{array}{l}\text { Strongl } \\
\text { y Agree }\end{array}$ & \\
\hline $\begin{array}{l}\text { I plan ahead and } \\
\text { make good choices. }\end{array}$ & 216 & 6 & 4.2 & 0.986 & 2.3 & 5.6 & 9.7 & 34.3 & 48.1 & 100 \\
\hline $\begin{array}{l}\text { I feel good about } \\
\text { myself. }\end{array}$ & 219 & 3 & 4.66 & 3.558 & 3.7 & 3.7 & 3.7 & 24.2 & 64.9 & 100 \\
\hline $\begin{array}{l}\text { I feel my future \& } \\
\text { life is under control }\end{array}$ & 220 & 2 & 4.3 & 1.057 & 4.1 & 2.7 & 12.3 & 20.5 & 60.5 & 100 \\
\hline $\begin{array}{l}\text { I deal with } \\
\text { frustrations in } \\
\text { positive ways. }\end{array}$ & 218 & 4 & 3.91 & 1.192 & 6 & 9.2 & 12.4 & 33 & 39.4 & 100 \\
\hline $\begin{array}{l}\text { Iam shaping my } \\
\text { purpose in life }\end{array}$ & 218 & 4 & 4.48 & 0.769 & 0.9 & 1.4 & 7.3 & 29.4 & 61 & 100 \\
\hline $\begin{array}{l}\text { Iam working on } \\
\text { personal health. }\end{array}$ & 216 & 6 & 4.48 & 0.795 & 0.9 & 2.8 & 5.1 & 29.6 & 61.6 & 100 \\
\hline
\end{tabular}

Findings indicated that $82.4 \%$ of the adolescents plan ahead of time and make good choices, $89.1 \%$ feel good about themselves and $80.5 \%$ feel their future is under control. Additionally, $72.4 \%$ perceive that they deal with frustrations in positive ways and $90.4 \%$ feel they are shaping their purpose in life. Furthermore $91.2 \%$ felt they are developing personal health habits. On the other hand, $17.6 \%$ do not plan ahead of time and do not make good choices, $11.1 \%$ do not feel good about themselves and $19.1 \%$ are uncertain about future and feel not in control. Additionally, 27.6\% of the adolescents confirmed that they do not deal with frustrations positively.

\section{Social Helpfulness, and Prosocial Behaviours:-}

Psychosocial adjustment on social helpfulness (altruism) was also investigated; the variable was examined using four items as shown in Table 4. It was found that $72.1 \%$ have the interest in helping others, $88 \%$ felt encouraged to help others while $84.6 \%$ confirmed to be developing interest to help others and $92.1 \%$ thought it is important to help others. It was noted that $36.9 \%$ are not interested in helping others.

Furthermore, adolescents' prosocial behaviours were also assessed using 11 items as shown on Table 4.10. The results showed that $69.8 \%$ of adolescents resolve conflicts without hurting others, $82.6 \%$ overcome challenges beneficially for themselves or others, while $91.6 \%$ accept people who are different from them and cannot make friendship with age mates. 
Additionally, 99.1\% make friends with peers, $68.8 \%$ express their feelings without hurting others while $93.6 \%$ confirmed that they are developing respect for others. Moreover, 59.4\% of the adolescents reported that they take responsibility for what they do, $74.4 \%$ make effort to make their communities better place, $87 \%$ work towards respecting others and $91 \%$ hold themselves responsible for their actions. It was noted that $51.4 \%$ of the adolescents tell the truth even when not easy. The mean on adolescents' development of prosocial behaviours was above 3.4 out of 5.0 which is above average.

Table 4. Adolescents' Social Helpfulness, and Prosocial Behaviours

\begin{tabular}{|c|c|c|c|c|c|c|c|c|c|}
\hline & \multicolumn{9}{|c|}{ Adolescents' Involvement in Social Helpfulness in Percentages } \\
\hline & $\mathrm{N}$ & Mean & Std. Dev & $\begin{array}{l}\text { Strongly } \\
\text { Disagre } \\
\mathrm{e}\end{array}$ & Disagree & $\begin{array}{l}\text { Not } \\
\text { Sure }\end{array}$ & Agree & $\begin{array}{r}\text { Strongly } \\
\text { Agree }\end{array}$ & $\begin{array}{r}\text { Tot } \\
\%\end{array}$ \\
\hline $\begin{array}{l}\text { Am interested in helping } \\
\text { others solve problems }\end{array}$ & 222 & 3.6 & 1.037 & 3.2 & 14.3 & 19.4 & 45.6 & 17.5 & 100 \\
\hline $\begin{array}{l}\text { Iam encouraged to help } \\
\text { others }\end{array}$ & 222 & 4.09 & 0.85 & 3.2 & 1.9 & 6.9 & 58.8 & 29.2 & 100 \\
\hline $\begin{array}{l}\text { Am developing a desire } \\
\text { to help others }\end{array}$ & 222 & 4.09 & 0.777 & 1.4 & 1.9 & 12.1 & 55.8 & 28.8 & 100 \\
\hline $\begin{array}{l}\text { I think it's important to } \\
\text { help others }\end{array}$ & 222 & 4.28 & 0.867 & 3.7 & 0.5 & 3.7 & 48.1 & 44 & 100 \\
\hline & \multicolumn{9}{|c|}{ Adolescents involvement in Prosocial Behaviours in Percentages } \\
\hline $\begin{array}{l}\text { Adolescents' Prosocial } \\
\text { Behaviours }\end{array}$ & $\mathrm{N}$ & Mean & Std. Dev & \begin{tabular}{|l|} 
Strongl \\
$\mathrm{y}$ \\
Disagre \\
$\mathrm{e}$
\end{tabular} & Disagree & $\begin{array}{l}\text { Not } \\
\text { Sure }\end{array}$ & Agree & $\begin{array}{l}\text { Strongly } \\
\text { Agree }\end{array}$ & $\begin{array}{r}\text { Tot } \\
\%\end{array}$ \\
\hline $\begin{array}{l}\text { I resolve conflicts } \\
\text { without hurting others. }\end{array}$ & 222 & 3.96 & 1.11 & 4.1 & 6.4 & 19.6 & 29.2 & 40.6 & 100 \\
\hline $\begin{array}{l}\text { I overcome challenges } \\
\text { beneficially to me and } \\
\text { others }\end{array}$ & 222 & 4.15 & 0.977 & 3.7 & 2.8 & 11 & 40.4 & 42.2 & 100 \\
\hline $\begin{array}{l}\text { I accept people who are } \\
\text { different to me }\end{array}$ & 222 & 4.42 & 0.791 & 1.4 & 1.9 & 5.1 & 37 & 54.6 & 100 \\
\hline $\begin{array}{l}\text { I make friendship with } \\
\text { age mates }\end{array}$ & 222 & 4.53 & 3.552 & 3.2 & 3.2 & 4.6 & 37.9 & 61.2 & 100 \\
\hline $\begin{array}{l}\text { I express my feelings } \\
\text { without hurting others. }\end{array}$ & 222 & 3.91 & 1.068 & 3.7 & 6 & 21.6 & 33 & 35.8 & 100 \\
\hline $\begin{array}{l}\text { Iam developing respect } \\
\text { for other people. }\end{array}$ & 222 & 4.51 & 0.713 & 0.9 & 0.9 & 4.6 & 33.3 & 60.3 & 100 \\
\hline $\begin{array}{l}\text { I take responsibility for } \\
\text { what I do truthfully }\end{array}$ & 222 & 3.46 & 1.024 & 4.6 & 15.1 & 21 & 48.4 & 11 & 100 \\
\hline $\begin{array}{l}\text { I make effort to make my } \\
\text { community a better plc }\end{array}$ & 222 & 3.91 & 0.941 & 2.8 & 4.7 & 18.1 & 47.4 & 27 & 100 \\
\hline $\begin{array}{l}\text { I am work towards } \\
\text { respecting others. }\end{array}$ & 222 & 4.13 & 0.819 & 1.9 & 2.8 & 8 & 54.9 & 32.4 & 100 \\
\hline $\begin{array}{l}\text { I hold myself responsible } \\
\text { for my actions }\end{array}$ & 222 & 4.23 & 0.784 & 1.4 & 2.8 & 4.7 & 53.3 & 37.7 & 100 \\
\hline $\begin{array}{l}\text { I tell the truth even when } \\
\text { not easy }\end{array}$ & 222 & 3.31 & 1.134 & 8.3 & 15.7 & 24.5 & 38.9 & 12.5 & 100 \\
\hline
\end{tabular}

In addition to the adjustment variable, the researcher also gathered data on adolescents' resilience to risky behaviours as shown in Table 5. It was found out that $81.1 \%$ stayed away from use of cigarettes, alcohol while $83 \%$ of the adolescents confirmed that they stayed away from dangerous and unhealthy habits. It was also noted that $84.4 \%$ resisted bad influence from other students. 
Table 5: Adolescents' Resiliency to Risky behaviours

\begin{tabular}{|c|c|c|c|c|c|c|c|c|c|}
\hline $\begin{array}{l}\text { Adolescents Involvement } \\
\text { in risky Behaviours }\end{array}$ & $\mathrm{N}$ & Mean & $\begin{array}{l}\text { Std. } \\
\text { Dev }\end{array}$ & $\begin{array}{l}\mathrm{S} / \\
\text { Disagree }\end{array}$ & $\begin{array}{l}\text { Disa } \\
\text { gree }\end{array}$ & N/Sure & $\begin{array}{l}\text { Agre } \\
\mathrm{e}\end{array}$ & S/Agree & Tot $\%$ \\
\hline & & & & \multicolumn{5}{|c|}{$\%$} & \\
\hline $\begin{array}{l}\text { I stay away from } \\
\text { cigarettes, alcohol and } \\
\text { drugs }\end{array}$ & 222 & 4.29 & 1.151 & 5.5 & 4.6 & 8.8 & 18 & 63.1 & 100 \\
\hline $\begin{array}{l}\text { I stay away from } \\
\text { dangerous unhealthy } \\
\text { habits. }\end{array}$ & 222 & 4.48 & 3.593 & 3.2 & 4.6 & 9.2 & 30 & 53 & 100 \\
\hline $\begin{array}{l}\text { I resist bad influences } \\
\text { from other students. }\end{array}$ & 222 & 4.27 & 1.026 & 5 & 0.9 & 9.6 & 31.2 & 53.2 & 100 \\
\hline
\end{tabular}

Correlates between Teacher- Student Relationship Supportiveness and Adolescents' Psychosocial adjustment:-

The supportiveness means score range of 1- 2.333 was considered as low supportiveness perception, 2.334 - 3.633 moderate supportiveness and 3.634- 5 adequate supportiveness. Equally, the psychosocial functioning scores were converted into mean scores. The mean scores for teacher- student relationship and the overall mean scores for adolescents' psychosocial adjustment, and its specific status were correlated using Pearson correlation coefficient as shown in Table 6. A correlation was considered statistically significant if the critical value was $p<.05$. A statistically significant correlation was obtained between positive teacher- student relationship and adolescents' psychosocial adjustment at $r 165^{*}, \mathrm{n} 222, \mathrm{p}=.014<.05$, adolescent' prosocial behaviours at $\mathrm{r} .170^{*}, \mathrm{n}=222, \mathrm{p} .011$.

Table 6:- Correlates between Teacher- student relationship Supportivess and Adolescents' Psychosocial adjustment

\begin{tabular}{|c|c|c|c|c|c|c|c|c|}
\hline & & $\begin{array}{l}\text { Psycho } \\
\text { social } \\
\text { adjustm } \\
\text { ent }\end{array}$ & $\begin{array}{l}\text { Students' } \\
\text { Industry }\end{array}$ & $\begin{array}{l}\text { Emoti } \\
\text { onality }\end{array}$ & $\begin{array}{l}\text { Self- } \\
\text { worth } \\
\text { and } \\
\text { Control }\end{array}$ & $\begin{array}{l}\text { Prosoci } \\
\text { al } \\
\text { Behavii } \\
\text { our }\end{array}$ & $\begin{array}{l}\text { Social } \\
\text { Helpfuln } \\
\text { ess }\end{array}$ & $\begin{array}{l}\text { Resilienc } \\
\text { y to Risky } \\
\text { Behaviour } \\
\text { s }\end{array}$ \\
\hline \multirow{3}{*}{$\begin{array}{l}\text { Teacher- } \\
\text { student } \\
\text { Relations } \\
\text { hip } \\
\text { supportiv } \\
\text { eness }\end{array}$} & $\begin{array}{l}\text { Pearson } \\
\text { Correlation }\end{array}$ & $.165^{*}$ & .031 & -.073 & .111 & $.170^{*}$ & $.149^{*}$ & $.204^{* * *}$ \\
\hline & $\begin{array}{l}\text { Sig. (2- } \\
\text { tailed) }\end{array}$ & .014 & .657 & .280 & .100 & .011 & .028 & .003 \\
\hline & $\mathrm{N}$ & 222 & 206 & 221 & 220 & 222 & 219 & 218 \\
\hline
\end{tabular}

$<.05$, social helpfulness at $\mathrm{r} .149^{*}, \mathrm{n}=219, \mathrm{p} .028<.05$, and resilience to risky behaviours at $\mathrm{r} .204^{*}, \mathrm{n}=218, \mathrm{p}$ $.003<.05$.

The null hypothesis that- School teacher- student relationships is not significantly related to adolescents' psychosocial adjustment was therefore rejected and the alternative hypothesis was adopted. However, teacherstudent relationship supportiveness was found not significantly related with adolescents' industry, emotionality, and self worth and control.

Correlation Analysis between teacher- student relationship Supportiveness variables and Adolescents' Psychosocial Adjustment Variables:-

Likert item scores on student- teacher relationships and adolescents' psychosocial adjustment in were correlated in order to identify the specific factors in the supportiveness that related with adolescents' traits of psychosocial adjustment. Spearman correlation coefficient was used since the measured aspects of school supportiveness were in ordered Likert items, while the dependent variables were in interval scale as shown in Table 7. A correlation was considered statistically significant if the critical value was $\mathrm{p}<.05$. The Spearman correlation findings between of student- teacher relationship supportiveness aspects and adolescents' psychosocial adjustment were computed as shown in Table 7. 
Table 7:- Correlation between teacher -student supportiveness and adolescents' psychosocial adjustment variables

\begin{tabular}{|c|c|c|c|c|c|c|c|c|}
\hline $\begin{array}{l}\text { Spearman } \\
\text { Rho }\end{array}$ & & $\begin{array}{l}\text { School } \\
\text { Adjustm } \\
\text { ent }\end{array}$ & $\begin{array}{l}\text { Students' } \\
\text { Emotional } \\
\text { ity }\end{array}$ & $\begin{array}{l}\text { Stude } \\
\text { nts' } \\
\text { Indust } \\
\text { ry }\end{array}$ & $\begin{array}{l}\text { Self- } \\
\text { worth } \\
\text { and } \\
\text { Control }\end{array}$ & $\begin{array}{l}\text { Prosoci } \\
\text { al } \\
\text { Behavii } \\
\text { our }\end{array}$ & $\begin{array}{l}\text { Social } \\
\text { Helpfuln } \\
\text { ess }\end{array}$ & $\begin{array}{c}\text { Resiliency } \\
\text { to Risky } \\
\text { Behaviour } \\
\text { s }\end{array}$ \\
\hline \multirow[t]{3}{*}{$\begin{array}{l}\text { Trs. show } \\
\text { Love, } \\
\text { care \& } \\
\text { respect. }\end{array}$} & $\begin{array}{l}\text { Correlatio } \\
\mathrm{n} \\
\text { Coefficie } \\
\mathrm{nt}\end{array}$ & .076 & $-.150^{*}$ & -.047 & .065 & $.154^{*}$ & .108 & $.139^{*}$ \\
\hline & $\begin{array}{l}\text { Sig. (2- } \\
\text { tailed) }\end{array}$ & .261 & .027 & .492 & .339 & .023 & .113 & .041 \\
\hline & $\mathrm{N}$ & 219 & 217 & 218 & 217 & 219 & 216 & 215 \\
\hline \multirow{3}{*}{$\begin{array}{l}\text { Trs.are } \\
\text { friendly } \\
\& \\
\text { concerned } \\
\text {. }\end{array}$} & $\begin{array}{l}\text { Correlatio } \\
\mathrm{n} \\
\text { Coefficie } \\
\mathrm{nt}\end{array}$ & .052 & -.118 & $-.152^{*}$ & .093 & $.156^{*}$ & .106 & .094 \\
\hline & $\begin{array}{l}\text { Sig. (2- } \\
\text { tailed) }\end{array}$ & .441 & .083 & .025 & .170 & .021 & .119 & .167 \\
\hline & $\mathrm{N}$ & 220 & 218 & 219 & 218 & 220 & 217 & 216 \\
\hline \multirow{3}{*}{$\begin{array}{l}\text { Lessons } \\
\text { are a } \\
\text { happy } \\
\text { experienc } \\
\text { e }\end{array}$} & $\begin{array}{l}\text { Correlatio } \\
\mathrm{n} \\
\text { Coefficie } \\
\mathrm{nt}\end{array}$ & $.152^{*}$ & .007 & -.038 & .087 & $.146^{*}$ & .121 & $.169^{*}$ \\
\hline & $\begin{array}{l}\text { Sig. (2- } \\
\text { tailed) }\end{array}$ & .024 & .922 & .573 & .201 & .031 & .074 & .013 \\
\hline & $\mathrm{N}$ & 221 & 219 & 220 & 219 & 221 & 218 & 217 \\
\hline \multirow[t]{3}{*}{$\begin{array}{l}\text { Trs. Help } \\
\text { when } \\
\text { disturbed. }\end{array}$} & $\begin{array}{l}\text { Correlatio } \\
\mathrm{n} \\
\text { Coefficie } \\
\mathrm{nt}\end{array}$ & $.148^{*}$ & -.052 & -.060 & .112 & $.257^{* *}$ & $.179^{* * *}$ & .109 \\
\hline & $\begin{array}{l}\text { Sig. (2- } \\
\text { tailed) }\end{array}$ & .029 & .447 & .381 & .100 & .000 & .008 & .110 \\
\hline & $\mathrm{N}$ & 219 & 218 & 218 & 218 & 219 & 216 & 215 \\
\hline \multirow[t]{3}{*}{$\begin{array}{l}\text { Trs.know } \\
\text { students } \\
\text { by name. }\end{array}$} & $\begin{array}{l}\text { Correlatio } \\
\mathrm{n} \\
\text { Coefficie } \\
\mathrm{nt}\end{array}$ & -.013 & -.051 & -.036 & -.108 & .085 & .087 & .080 \\
\hline & $\begin{array}{l}\text { Sig. (2- } \\
\text { tailed) }\end{array}$ & .846 & .452 & .592 & .110 & .209 & .200 & .238 \\
\hline & $\mathrm{N}$ & 221 & 219 & 220 & 219 & 221 & 218 & 217 \\
\hline \multirow[t]{3}{*}{$\begin{array}{l}\text { Trs. are } \\
\text { always } \\
\text { helpful }\end{array}$} & $\begin{array}{l}\text { Correlatio } \\
\mathrm{n} \\
\text { Coefficie } \\
\mathrm{nt}\end{array}$ & $.149^{*}$ & -.041 & -.041 & .108 & $.185^{* *}$ & .109 & $.199^{* * *}$ \\
\hline & $\begin{array}{l}\text { Sig. (2- } \\
\text { tailed) }\end{array}$ & .028 & .547 & .550 & .112 & .006 & .110 & .003 \\
\hline & $\mathrm{N}$ & 220 & 218 & 219 & 218 & 220 & 217 & 216 \\
\hline
\end{tabular}

**. Correlation is significant at the 0.01 level (2-tailed).

*. Correlation is significant at the 0.05 level (2-tailed).

The findings indicated that teachers show of love, care and respect was statistically significantly negatively correlated with adolescents' emotionality at $r_{s}-.150^{*}, \mathrm{n}=217, \mathrm{p} .027<.05$, prosocial behaviour at $r_{s} .154^{*}, \mathrm{n}=219$, $\mathrm{p} .023<.05$, and resiliency to risky behaviours at $r_{s} .139^{*}, \mathrm{n}=215, \mathrm{p} .041<.05$. The findings on the contrary revealed that teachers show of love, care and respect to adolescents' does not significantly relate to adolescents' industry, self worth and control and social helpfulness at $\mathrm{p}>.05$, and does not significantly correlate with overall 
psychosocial adjustment. Teachers friendliness and concern was statistically significantly correlated with adolescents' industry at $r_{s}-.152^{*}, \mathrm{n}=219, \mathrm{p} .025<.05$, and prosocial behaviours at $r_{s} .156^{*}, \mathrm{n}=220, \mathrm{p} .021<.05$.

Teachers' friendliness and concern was not found to be significantly linked with adolescents' emotionality, self worth and control, social helpfulness and resiliency to risky behaviours, as well as overall psychosocial adjustment at $\mathrm{p}>.05$. Furthermore, teacher making lessons a happy experience was positively statistically correlated with adolescents' overall psychosocial adjustment at $r_{s} .152^{*}, \mathrm{n}=221, \mathrm{p} .024<.05$, prosocial behaviours at $r_{s} .146^{*}, \mathrm{n}=$ $221, \mathrm{p} .031<.05$, and resiliency to risky behaviours at $r_{s} .169^{*}, \mathrm{n}=217, \mathrm{p} .013<.05$, as well as overall psychosocial adjustment at $r_{s} .152^{*}, \mathrm{n}=221, \mathrm{p} .024<.05$. Teachers making lessons a happy experience was not found to be related to adolescents' emotionality, industry, self-worth and control and social helpfulness at the alpha value .05 .

In addition, helping students when disturbed was found positively statistically significantly correlated with adolescents' overall psychosocial adjustment at $r_{s} .148^{*}, \mathrm{n}=219, \mathrm{p} .029<.05$. Prosocial behaviours at $r_{s} .257^{* *}, \mathrm{n}$ $=219, \mathrm{p} .000<.05$, and social helpfulness at $r_{s} .179^{* *}, \mathrm{n}=218, \mathrm{p} .008<.05$, as well as overall psychosocial adjustment at $r_{s} .148^{*}, \mathrm{n}=219, \mathrm{p} .029<.05$. There was no significant correlation between helping disturbed students and adolescents' emotionality, industry self worth and control as well as resiliency to risky behaviours at $p$ $>.05$.

The act of being always helpful to students was found positively statistically correlated with adolescents' overall psychosocial adjustment at $r_{s} .149^{*}, \mathrm{n}=220, \mathrm{p} .028<.05$, prosocial behaviours at $\mathrm{rs} .185^{* *}, \mathrm{n}=220, \mathrm{p} .006<.05$, and resiliency to risky behaviours at $r_{s} .199^{*}, \mathrm{n}=216, \mathrm{p} .0003<.05$. Teachers' being always helpful was found not significantly related to adolescents' emotionality, industry and self control and worth as well as social helpfulness at $\mathrm{p}>.05$. Finally, teachers' knowledge of student by name was found not related to any of the psychosocial adjustment behaviours under investigation at $\mathrm{p}>.05$.

In summary, overall psychosocial adjustment was related to happy classroom experiences, teachers helping students when disturbed and being always helpful. Students' negative emotionality was linked with teachers' being loving, caring, while adolescents' industry, self control and worth were not linked to any of the student- teacher relationship variables. Nonetheless, adolescents' prosocial behaviours were associated with teachers being loving and caring, friendly and concerned, class lessons being a happy experience and students getting help from teachers when always disturbed. Adolescent's social helpfulness was linked to their getting help from teachers while disturbed, while resilience to risky behaviours was associated with teachers being loving and caring, happy classroom experiences, and teachers being always helpful. However, knowing student by name was not found to correlate statististically significantly with any of the psychosocial adjustment variables at $\mathrm{p}>.05$.

\section{Discussion:-}

Relationship between Teacher- Student Relationship Supportiveness and Adolescents' Psychosocial Adjustment Overall school teacher-student relationship supportiveness was found significantly positively related to adolescents' prosocial behaviours, social helpfulness and resiliency to risky behaviours. It is therefore concluded that positive relationships between teachers and students has some influence on adolescents' development of prosocial behaviours, social helpfulness and resilience to risky behaviours. However, the relationship was found not to be linked to emotionality, industry, self control and self worth forms of psychosocial adjustment.

The critical aspects of supportiveness in predicting psychosocial adjustment were happy classroom experiences with teachers, teachers helping students when disturbed, being always helpful. Teachers positive relationships with students by being loving and caring, friendly and concerned, influenced adolescents' prosocial behaviours, class lessons being a happy experience, and students getting help from teachers when disturbed. Teachers providing help to students was positively linked with adolescents' social helpfulness while being loving, caring, providing happy classroom experiences to students and being always helpful to them positively linked to adolescents' prosocial behaviours. It was also noted that teachers' being loving, caring, was found negatively linked to adolescents' emotionality, which means the negative emotionality would reduce.. However, adolescents' industry, self control and worth were not linked to any of the teacher- student relationship variables.

These research findings concur with findings that reveal perceptions of positive teacher- student relationships (supportiveness, responsiveness, and care) leads to fewer behaviour problems (Loukas \& Robinson, 2004; Wang, 
2009). Further, the findings are consistent with Birch and Ladd (1998) and Hamre and Pianta, (2001) result that show that strong supportive teacher- student relationships are significant in healthy development of students. It is thought that the positive relationships provide some psychological cushion against maladjustment in school. In concurrence Crosnoe, Johnson, and Elder, (2004) finding reveal that positive relations helps in adjustment and connection with significant adults in schools is important across all ages. Gregory and Weinstein, (2004); Hamre and Pianta, (2001) also concedes that student-teacher relationships contributes to social-emotional development. Furthermore, Hughes, Cavell and Willson (2001) also agree that teacher- student positive relationships help children at risk for behavioural problems to learn more adaptive behaviour. In same breathe, Meehan, Hughes, and Cavell, (2003) results are in agreement that supportive student-teacher relationships were associated with declines in aggressive behaviour between second and third grade. In fact, positive connection with teachers has rated more important than family and is a greater predictor of students' achievement among 8th to 12th grade (Gregory \& Weinstein, 2004).

Hamre and Pianta (2003) in agreement notes that positive teacher-student relationships should be enhanced through explicit teaching of social and emotional skills, increase on amount of time that students and teachers spend together, expanded adult network, as well as developing disciplinary practices that set high expectations for students and foster caring relationship. They also suggested increased teachers availability to students, positive regard, frequent social conversations with students, and use behaviour management strategies that communicate care and expected behaviour. It was not clear why there was no relationship between teacher student relationship and adolescents, industry and self control and worth.

\section{Conclusion:-}

Teachers should adopt a warm, friendly, caring and concerned attitude towards their students, to will enhance adolescents' psychosocial adjustment. It is therefore recommended that the Ministry of Education conducts inservice courses for teachers with the intent of enhancing students' social helpfulness, prosocial behaviours and resiliency to risky behaviours as well as overall psychosocial adjustment. These findings are applicable also to young adulthood students.

\section{Recommendations:-}

It is recommended that this study be replicated with the inclusion of teachers as part of the respondents. Additionally, a causal study can be conducted along similar variables to establish the actual cause and effect relationships, and finally, a longitudinal survey can be conducted to establish the long-term effects of school supportiveness on young adults' psychosocial adjustment.

\section{References:-}

1. Ajowi . Jack. O., \& Ambato C., J. (2013). Preparedness of Teachers to Maintain Discipline in the Absence of Corporal Punishment in Bondo District Kenya. Journal of Educational and Social Research, 3 (2)

2. Aloka, P., J. \& Bujuwoye, O. (2013). Gender differences in decisions on student disciplinary behaviours by disciplinary panels of selected Kenyan secondary schools. African Journals Online, 5252-5271.

3. Battistich, V., Schaps, E., Watson, M., Solomon, D., \& Lewis, C. (2000). Effects of the Child Development Project on students' drug use and other problem behaviors. Journal of Primary Prevention, 21(1), 75-99.

4. Benson, C. (2002). Bilingual education in Africa: An exploration of encouraging connections between language and girls' schooling. Education-A Way out of Poverty, 79-95.

5. Bernard, B. \& Slade, S. (2009) Listening to Students: Moving from Resilience Research to Youth Development Practice and School Connectedness in Handbook of Positive Psychology in Schools with Gilman, R., Heubner, S. \& Furlong, M., (Eds.), New York: Routledge, 353-370.

6. Birch, S. H., \& Ladd, G. W. (1998). Children's interpersonal behaviors and the teacher-child relationship. Developmental Psychology, 34(5), 934.

7. Bryk, A. S. (2010). Organizing schools for improvement. Phi Delta Kappan, 91(7), 23.

8. Catalano, R. F., Berglund, M. L., Ryan, J. A., Lonczak, H. S., \& Hawkins, J. D. (2002). Positive youth development in the United States: Research findings on evaluations of positive youth development programs. Prevention \& Treatment, 5(1), 15a.

9. Catalano, R.E., Berglund, M.L. Ryan, J. A.M., Lonczak, H.S., Hawkins, J. D. (1999). Positive Youth Development in the United States: Research Findings on Evaluations of Positive Youth Development Programs. Seattle: Washington. Available at http://aspe.hhs.gov/pic/pdf/6878.pdf 
10. Centers for Disease Control and Prevention. (2007). The effectiveness of universal school-based programs for the prevention of violent and aggressive behavior. $M M W R$, 56:1-11. No. RR-7. Available at http://www.cdc.gov/mmwr/pdf/rr/rr5607

11. Constitution, K. (2010). Government Printer. Nairobi, Kenya.

12. Cowen, R. (2000). Comparing futures or comparing pasts? Comparative Education, 36(3), 333-342.

13. Crosnoe, R., Johnson, M. K., \& Elder, G. H. (2004). Intergenerational bonding in school: The behavioral and contextual correlates of student-teacher relationships. Sociology of Education, 77(1), 60-81.

14. EMIS Kenya, (2007). Educational statistical booklet. Ministry of Education.

15. Gay, L. R. (1992). Educational research: Competence for analysis and application (4 ${ }^{\text {th }}$ Edition). New Yorkk: Macmillan Publishers.

16. Gomez B. J (2005). Adolescent Psychosocial Functioning and School Supportiveness In Malaysia; Thesis, The Pennsylvania State University.

17. Gregory, A., \& Weinstein, R. S. (2004). Connection and regulation at home and in school: Predicting growth in achievement for adolescents. Journal of Adolescent Research, 19, 405-427.

18. Hamre, B. K., \& Pianta, R. C. (2004). Self-reported depression in nonfamilial caregivers: Prevalence and associations with caregiver behavior in child-care settings. Early Childhood Research Quarterly, 19, 297-318.

19. Hamre, B. K., \& Pianta, R. C. (2001). Early teacher-child relationships and the trajectory of children's school outcomes through eighth grade. Child Development, 72(2), 625-638.

20. Howell, D., Oliver, T. K., Keller-Olaman, S., Davidson, J., Garland, S., Samuels, C., ... others. (2013). A PanCanadian practice guideline: prevention, screening, assessment, and treatment of sleep disturbances in adults with cancer. Supportive Care in Cancer, 21(10), 2

21. Hughes, J. N., Cavell, T. A., \& Willson, V. (2001). Further support for the developmental significance of the quality of the teacher-student relationship. Journal of School Psychology, 39, 289-302.

22. Kariuki, S. N. (2016). School Supportiveness and Adolescents' Psychosocial Adjustment. Daystar University. Unpublished.

23. Kothari, C. R. (2004). Research methodology: Methods and techniques. New Age International.

24. Kyriakides, L. (2005). Drawing from teacher effectivess research and research into teacher interpersonal behaviour to establish a teacher evaluation system: A study on the use of student ratings to evaluate teacher behaviour. The Journal of Classroom Interaction, 44-66.

25. Lampley, J.H. \& Johnson, K.C. (2010). Mentoring At-risk Youth: Improving Academic Achievement in Middle School Students. Nonpartisan Education Review, 6 (1). Available at http://npe.educationnews.org/Review/Articles/v6n1.pdf.

26. Leffert, N., Benson, P. L., Scales, P. C., Sharma, A. R., Drake, D. R., \& Blyth, D. A. (1998). Developmental assets: Measurement and prediction of risk behaviors among adolescents. Applied Developmental Science, 2(4), 209-230.

27. Lerner, R. M., \& Castellino, D. R. (2002). Contemporary developmental theory and adolescence: Developmental systems and applied developmental science. Journal of Adolescent Health, 31(6), 122-135.

28. Loukas A, Robinson S. (2004). Examining the moderating role of perceived school climate in early adolescent adjustment. Journal of Research on Adolescence; 14:209-233.

29. Meece, J. L., \& Eccles, J. S. (2010). Handbook of research on schools, schooling and human development. Routledge. Retrieved from https://books.google.com/books?hl=en\&lr=\&id=ntNAgAAQBAJ\&oi=fnd\&pg=PP1\&dq=(Meece+\%26+Eccles, +2010$) .+\& o t s=u l 17 d j 8 a 1 T \& s i g=M 79 G e 73 G Z k z K$ 0c9aiBVNQ4FSIkc

30. Meehan, B. T., Hughes, J. N., \& Cavell, T. A. (2003). Teacher-student relationships as compensatory resources for aggressive children. Child Development, 74, 1145-1157.

31. Ministry of Public Health and Sanitation, \& Ministry of Education. (2011-2015). National School Health Strategy Implementation Plan 2011-2015. Retrieved from https://child.org/sites/default/files/KenyaNationalSchoolHealthStrategy.

32. MoE (2012). A Policy Framework for Education: Aligning Education and Training to the Constitution of Kenya (2010) and Kenya Vision 2030 and beyond.

33. Morrison, F. J., \& Connor, C. M. (2002). Understanding schooling effects on early literacy: A working research strategy. Journal of School Psychology, 40(6), 493-500.

34. Mugenda, G. A. (2008). Social science research: Theory and principles. Nairobi: Kijabe Printing Press.

35. Ndetei DM, Khasakhala LI, Mutiso V, Ongecha-Owuor FA, Kokonya DA (2009). Psychosocial and health aspects of drug use by students in public secondary schools in Nairobi, Kenya. Psychosocial and health aspects of drug use: Pub Med 30(1) 61-8. 
36. Nye, I. F. (1958). Family relationships and delinquent behavior. New York: John Wiley \& Sons.

37. Nye, B., Konstantopoulos, S., \& Hedges, L. V. (2004). How large are teacher effects? Educational Evaluation and Policy Analysis, 26(3), 237-257.

38. Olsson, C. A., Bond, L., Burns, J. M., Vella-Brodrick, D. A., \& Sawyer, S. M. (2003). Adolescent resilience: A concept analysis. Journal of Adolescence, 26(1), 1-11.

39. Peterson, K. D., Wahlquist, C., \& Bone, K. (2000). Student surveys for school teacher evaluation. Journal of Personnel Evaluation in Education, 14(2), 135-153.

40. Pittman, K. J., Irby, M., Tolman, J., Yohalem, N., \& Ferber, T. (2011). Preventing problems, promoting development, encouraging engagement. In Washington, DC: Forum for Youth Investment. Retrieved from http://dev.forumfyi.org/files/Preventing\%20Problems, \%20Promoting\%20Development, \%20Encouraging\%20E ngagement.pdf

41. Robson, C. (2002). Real world research ( $7^{\text {th }}$ eds.), UK Library of Congress.

42. Roeser, R. W., Eccles, J. S., \& Sameroff, A. J. (2000). School as a context of early adolescents' academic and social-emotional development: A summary of research findings. The Elementary School Journal, 443-471.

43. Roth, J. L., \& Brooks-Gunn, J. (2003). What exactly is a youth development program? Answers from research and practice. Applied Developmental Science, 7(2), 94-111.

44. The Daily Nation. (2016, August 7). Shock as students smoke bhang, drink booze on bus. Retrieved from http://www.nation.co.ke/news/students-drug-party-on-bus/1056-2822836-15a7bav/index.html

45. UNICEF. (2006). The state of the world's children 2007: Women and children: The double dividend of gender equality (Vol. 1 7). Unicef. https://books.google.com/books?hl=en\&lr=\&id=HiIZr4QFkOMC\&oi=fnd\&pg=PR6\&dq=UNICEF+(2006), +\& ots=15O1Lb2Nap\&sig=MG-7BfjSCxt9snAgSPTu7Yfuz5s

46. Wang, J., Lannotti, R. J., \& Nansel, T. R. (2009). School bullying among US adolescents: Physical, verbal, relational, and cyber. Journal of Adolescent Health, 45, $368-375$.

47. Welsh, J. A., \& Bierman, K. L. (2001). Encyclopedia of childhood and adolescence. The Pennsylvania State University.

48. Zaff, J. F., Smith, D. C., Rogers, M. F., Leavitt, C. H., Halle, T. G., \& Bornstein, M. H. (2003). Holistic wellbeing and the developing child. Well-Being: Positive Development across the Life Course, 23-32. 